\title{
A Comparative Study of Biodegradation of Nickel and Chromium from Space Maintainers: An in vitro Study
}

\author{
${ }^{1}$ Ashish Anand, ${ }^{2}$ Arun Sharma, ${ }^{3}$ Piush Kumar, ${ }^{4}$ Meera Sandhu, ${ }^{5}$ Shobhit Sachdeva, ${ }^{6}$ Vinod Sachdev
}

\begin{abstract}
Objective: The aim of the study was to compare and evaluate the in vitro biodegradation of nickel and chromium from space maintainers, made of three different companies, i.e (Dantaurum, Rocky mountain and Dtech) in artificial saliva.

Materials and methods: The study comprised of 30 space maintainers out of which 10 were fabricated using Dantaurum, 10 using Rocky mountain and 10 using Dtech band materials. Stainless steel wire (Dantaurum, Rocky mountain and Konark) was used for making loops and Leone solder and flux was used for soldering. Each group was further divided into four subgroups containing 1, 2, 3 and 4 space maintainers respectively. The space maintainers in each subgroup were placed in separate glass beakers containing $100 \mathrm{ml}$ of artificial saliva at $37^{\circ} \mathrm{C}$ for 4 weeks. Salivary samples from each beaker was analyzed for nickel and chromium ions separately on days 1, 7, 14, 21 and 28 days using inductively coupled plasma-optical emission spectrophotometer.
\end{abstract}

Results: Total release of nickel and chromium from all band and loop space maintainers ranged from 0.020 to $1.524 \mathrm{ppm}$ and 0.002 to $0.289 \mathrm{ppm}$ respectively. The release of nickel and chromium between the groups and within the groups was not significant $(p<0.5)$.

Conclusion: There was no substantial release of nickel and chromium from space maintainers made of Dantaurum, Rocky mountain and Dtech which could cause any toxicity.

Keywords: Artificial saliva, Chromium, Nickel, Space maintainers.

How to cite this article: Anand A, Sharma A, Kumar P, Sandhu M, Sachdeva S, Sachdev V. A Comparative Study of Biodegradation of Nickel and Chromium from Space Maintainers: An in vitro Study. Int J Clin Pediatr Dent 2015; 8(1):37-41.

\footnotetext{
${ }^{1}$ Postgraduate Student, ${ }^{2,6}$ Professor and Head

${ }^{3}$ Associate Professor, ${ }^{4}$ Professor, ${ }^{5}$ Senior Lecturer

1,4-6 Department of Pedodontics and Preventive Dentistry, ITS Centre for Dental Studies and Research, Muradnagar, Uttar Pradesh, India

${ }^{2}$ Department of Pedodontics and Preventive Dentistry, Institute of Dental Studies and Technologies, Modinagar, Uttar Pradesh India

${ }^{3}$ Department of Orthodontics, ITS Centre for Dental Studies and Research, Muradnagar, Uttar Pradesh, India
}

Corresponding Author: Meera Sandhu, Professor Department of Pedodontics and Preventive Dentistry, ITS Centre for Dental Studies and Research, Muradnagar Ghaziabad, Uttar Pradesh, India, Phone: 09999553928, e-mail: meerapedo@yahoo.co.in

\section{Source of support: Nil \\ Conflict of interest: None}

\section{INTRODUCTION}

Stainless steel crowns and space maintainers are widely used in pediatric dentistry. These are made-up of base metal alloys along with iron, nickel and chromium as the main constituents. Nickel is incorporated in all austenitic stainless steel alloys to stabilize the austenitic phase, improve the tarnish resistance of the alloy, and decrease the ductility, while chromium is added to facilitate the formation of anticorrosive passivating film on the alloy surface. $^{1}$

The warm and moist oral aerobic condition in the mouth offers an aggressive environment for electrolytic and electrochemical activity, thus offering an ideal environment for the biodegradation of metals consequently facilitating the release of metals and their corrosion products. ${ }^{2}$

The release of metal ions, especially nickel from dental alloys, is a possible concern because of its local and systemic toxicity, immunogenic, mutagenic and chemostatic effects. ${ }^{3}$ There is a possibility of nickel and chromium released from space maintainers, stainless steel orthodontic bands, brackets and wires eliciting an adverse reaction.

The nickel content in glandular saliva is largely influenced by dietary intake. ${ }^{4}$ Potential health effects from exposure to nickel and chromium include hypersensitivity, allergic reaction and ulceration of oral mucosa. Nickel complexes in the form of arsenides and sulphides can be carcinogenic and mutative; even at nontoxic concentrations nickel might induce DNA alterations mainly through base damage and DNA- strand scission. ${ }^{5}$ Besides originating from orthodontic appliances, nickel may be accumulated from saliva and food.

The present study was carried out to evaluate in vitro biodegradation of space maintainers made of three different company band materials (Dantaurum, Rocky mountain and Dtech) using Inductively coupled plasmaoptical emission spectrophotometer and to also evaluate the concentration of nickel and chromium ions present in salivary samples following 1, 7, 14, 21 and 28 days. 


\section{MATERIALS AND METHODS}

The present study was carried out in the Department of Pedodontics and Preventive Dentistry at ITS Centre for Dental Studies and Research and National Test house, Ghaziabad, Uttar Pradesh.

The study comprised of 30 space maintainers out of which 10 were fabricated using Dantaurum, 10 using Rocky mountain and 10 using Dtech band materials. Each group of 10 space maintainers were further divided into four subgroups. Subgroups 1, 2, 3 and 4 containing 1, 2, 3 and four space maintainers respectively.

\section{Methodology}

Ideal casts were obtained simulating second primary molar. Band and loop space maintainers were fabricated on first permanent mandibular molar. Ten space maintainers were fabricated using Dantaurum wire and bands, 10 were fabricated using Rocky mountain wire and band and 10 were fabricated using Dtech bands and Konark wire. Leon solder and flux were used for soldering. They were later trimmed and polished.

The space maintainers in each subgroup were placed in separate glass beakers containing $100 \mathrm{ml}$ of artificial saliva at $37^{\circ} \mathrm{C}$ for 4 weeks. The required amount of salivary sample was drawn out from each beaker and analysed for nickel and chromium ions separately on days $1,7,14,21,28$ days using inductively coupled plasmaoptical emission spectrophotometer.

Measurement techniques: The analysis was performed by inductively coupled plasma-optical emission spectrophotometer (Model no. Optima DV 2100 make perkin element) which was based on the principle of emission technology. The minimum detection limit of this instrument was 0.1 parts per billion. It was based on the principle of emission technology. The test solution was nebulized by the nebuliser and sprayed in plasma chamber, where electron was emitted on the particular wavelength of the particular element in the presence of plasma (at very high temp, i.e $12000 \mathrm{~K}^{\circ}$ ). The elements in the solution were determined qualitatively and quantitatively from the wavelengths and intensities of the emissions from excited atoms and ions of the emissions spectra utilized for element determination, the emission spectra from atoms were classified as neutral lines, and the emission spectra from ions were classified as ionic lines.

Procedure: Two percent nitric acid was used as a calibration blank. The instrument makes the background zero then the calibration of instrument was performed. For calibration standards of elements which were detected in the samples were taken and accurate standards for calibration were obtained which has international tracebility. For calibration, nickel and chromium having concentration of $0.01,0.5,1.0,5.0,10.0 \mathrm{ppm}$ or $\mathrm{mg} / \mathrm{l}$ was used. After using the standard of $0.01,0.5,1.0,5.0,10.0 \mathrm{ppm}$, nickel and chromium solution (prepared in $2 \% \mathrm{HNO}_{3}$ blank) calibration graph was plotted which was in the form of a linear line and the correction factor should be 0.9899 to 0.9999 . In the study undertaken, the correction factor of nickel and chromium was 0.9999 .

After calibration of instrument, analysis of the samples for nickel and chromium was done where ultrapure water was used, which was having highest purity. The samples reading were taken atleast three times, the average values of three readings was taken as a final value.

\section{RESULTS}

Thirty space maintainers (band and loop) made of three different materials were used for the purpose of study. These space maintainers were placed in separate glass beakers containing $100 \mathrm{ml}$ of artificial saliva at $37^{\circ} \mathrm{C}$ for 4 weeks and release of nickel and chromium from space maintainer were evaluated. Total release of nickel and chromium from all band and loop space maintainers ranged from 0.020 and $1.524 \mathrm{ppm}$ (Tables 1 and 2) and 0.002 to 0.289 (Tables 3 and 4) ppm respectively. The release of nickel and chromium between the groups and within groups was not significant $(\mathrm{p}<0.5)$ (Tables 3 and 4).

\section{DISCUSSION}

Metallic alloys are routinely used in dentistry in a variety of applications like fabrication of orthodontic appliances, fabrication of prosthetic appliances and indirect restoration of teeth. Most metallic alloys have definite composition of their own; usually varying from one another with one thing common among all that is the occurrence of trace elements. ${ }^{6}$

There has been an increased interest among dental and biomedical professionals regarding the side effects associated with the use of metallic materials, specially biomaterials.

The general mechanism for the corrosion and subsequent release of metal ions from stainless steel involves loss of the passivating layer of chromium oxide and chromium hydroxide that forms on the surface upon contact with oxygen. ${ }^{7,8}$

Nickel is a strong sensitizer and one of the most common cause of contact allergies and has carcinogenic and mutagenic effects. Allergic response to nickel-containing alloys is mainly type 4 hypersensitivity reaction, i.e. cell mediated reaction by t-lymphocytes. It has been suggested that long-term exposure to nickel-containing 
A Comparative Study of Biodegradation of Nickel and Chromium from Space Maintainers: An in vitro Study

Table 1: Release of nickel ions in subgroups 1 and 2 in ppm

\begin{tabular}{|c|c|c|c|c|c|c|c|c|c|c|c|}
\hline \multirow{2}{*}{ Days } & & \multicolumn{4}{|c|}{ Release of nickel ions in subgroup 1 in ppm } & \multicolumn{6}{|c|}{ Release of nickel ions in subgroup 2 in ppm } \\
\hline & & Dantaurum & \multicolumn{2}{|c|}{ Rocky mountain } & Dtech & \multicolumn{2}{|c|}{ Dantaurum } & \multicolumn{3}{|c|}{ Rocky mountain } & Dtech \\
\hline \multicolumn{2}{|l|}{1} & Nil & 0.026 & & Nil & Nil & & 0.02 & & & Nil \\
\hline \multicolumn{2}{|l|}{7} & Nil & 0.044 & & Nil & Nil & & 0.03 & & & Nil \\
\hline \multicolumn{2}{|l|}{14} & Nil & Nil & & Nil & Nil & & $0.02 \varepsilon$ & & & Nil \\
\hline \multicolumn{2}{|l|}{21} & Nil & Nil & & Nil & Nil & & Nil & & & Nil \\
\hline \multicolumn{2}{|l|}{28} & Nil & Nil & & Nil & Nil & & Nil & & & Nil \\
\hline \multicolumn{2}{|c|}{ Total release (ppm) } & Nil & 0.070 & & Nil & Nil & & 0.08 & & & Nil \\
\hline \multirow[b]{2}{*}{$\begin{array}{l}\text { Source of } \\
\text { variance }\end{array}$} & \multicolumn{5}{|c|}{ Analysis of variance for nickel in subgroup 1} & \multicolumn{6}{|c|}{ Analysis of variance for nickel in subgroup 2} \\
\hline & $\begin{array}{l}\text { Sum of } \\
\text { squares }\end{array}$ & $\begin{array}{l}\text { Degree of freedom } \\
\text { (DF) }\end{array}$ & $\begin{array}{l}\text { Mean } \\
\text { square }\end{array}$ & $\begin{array}{l}\text { Variance } \\
\text { ratio }(F)\end{array}$ & $p$-value & $\begin{array}{l}\text { Sum of } \\
\text { squares }\end{array}$ & $\begin{array}{l}\text { Degree } \\
(D F)\end{array}$ & dom & $\begin{array}{l}\text { Mean } \\
\text { square }\end{array}$ & $\begin{array}{l}\text { Variance } \\
\text { ratio }(F)\end{array}$ & $p$-value \\
\hline $\begin{array}{l}\text { Between } \\
\text { materials }\end{array}$ & 0.001 & 2 & 0.000 & 2.402 & 0.133 & 0.001 & 2 & & 0.000 & 5.217 & 0.023 \\
\hline Within days & 0.002 & 12 & 0.000 & & & 0.001 & 12 & & 0.000 & & \\
\hline Total & 0.002 & 14 & & & & 0.002 & 14 & & & & \\
\hline
\end{tabular}

Table 2: Release of nickel ions in subgroups 3 and 4 in ppm

\begin{tabular}{|c|c|c|c|c|c|c|c|c|c|c|c|}
\hline \multirow[b]{2}{*}{ Days } & & \multicolumn{5}{|c|}{ Release of nickel ions in subgroup 3 in ppm } & \multicolumn{5}{|c|}{ Release of nickel ions in subgroup 4 in ppm } \\
\hline & & \multicolumn{2}{|l|}{ Dantaurum } & \multicolumn{2}{|l|}{ Rocky mountain } & Dtech & \multicolumn{2}{|c|}{ Dantaurum } & \multicolumn{2}{|c|}{ Rocky mountain } & Dtech \\
\hline 1 & & \multicolumn{2}{|l|}{0.139} & 0.112 & & 0.012 & \multicolumn{2}{|c|}{1.177} & \multicolumn{2}{|c|}{0.107} & Nil \\
\hline 7 & & \multicolumn{2}{|l|}{0.227} & 0.153 & & Nil & \multicolumn{2}{|c|}{1.524} & \multicolumn{2}{|l|}{0.129} & Nil \\
\hline 14 & & \multicolumn{2}{|l|}{0.233} & 0.177 & & Nil & \multicolumn{2}{|c|}{1.157} & \multicolumn{2}{|l|}{0.04} & 0.009 \\
\hline 21 & & \multicolumn{2}{|l|}{ Nil } & Nil & & Nil & \multicolumn{2}{|l|}{ Nil } & \multicolumn{2}{|l|}{ Nil } & Nil \\
\hline 28 & & \multicolumn{2}{|l|}{ Nil } & Nil & & Nil & \multicolumn{2}{|l|}{ Nil } & \multicolumn{2}{|l|}{ Nil } & Nil \\
\hline \multicolumn{2}{|c|}{ Total release (ppm) } & \multicolumn{2}{|l|}{0.599} & 0.442 & & 0.012 & 3.8 & & 0.276 & & 0.009 \\
\hline & & alysis of varia & ance for 1 & nickel in subgrout & & & & nalysis of var & ance for 1 & ickel in subgrou & p 4 \\
\hline $\begin{array}{l}\text { Source of } \\
\text { variance }\end{array}$ & $\begin{array}{l}\text { Sum of } \\
\text { squares }\end{array}$ & $\begin{array}{l}\text { Degree of } \\
\text { freedom } \\
\text { (DF) }\end{array}$ & $\begin{array}{l}\text { Mean } \\
\text { square }\end{array}$ & $\begin{array}{l}\text { Variance ratio } \\
(F)\end{array}$ & $p$-value & & & $\begin{array}{l}\text { Degree of } \\
\text { freedom } \\
\text { (DF) }\end{array}$ & $\begin{array}{l}\text { Mean } \\
\text { square }\end{array}$ & $\begin{array}{l}\text { Variance ratio } \\
(F)\end{array}$ & $p$-value \\
\hline $\begin{array}{l}\text { Between } \\
\text { materials }\end{array}$ & 0.037 & 2 & 0.018 & 2.713 & 0.107 & & & 2 & 0.924 & 5.319 & 0.022 \\
\hline Within days & 0.082 & 12 & 0.007 & & & & & 12 & 0.174 & & \\
\hline Total & 0.119 & 14 & & & & & & 14 & & & \\
\hline
\end{tabular}

dental materials may adversely affect both human monocytes and oral mucosal cells. In addition to nickel, chromium and cobalt ions also cause hypersensitivity and dermatitis. These metals can also induce cytotoxicity and genotoxicity. ${ }^{9}$

In present study, release of nickel and chromium from space maintainers was measured on 1, 7, 14, 21 and 28 days keeping each subgroup in $100 \mathrm{ml}$ of artificial saliva.

Inductively coupled plasma: Optical emission spectrophotometer was used to analyze nickel and chromium from space maintainers.

Total release of nickel in groups 1, 2, 3 and 4 at the given days was nil in groups 1 and 2 for Dantauram and Dtech, and 0.070 and 0.085 respectively, from Rocky mountain. In subgroup 3, it was 0.599, 0.442 and 0.012 for Dantauram, Rocky mountain and Dtech respectively. In subgroup 4, Dantauram showed maximum release of nickel out of three bands with a release of up to $3.858 \mathrm{ppm}$. For Rocky mountain and Dtech, the total release was 0.276 and 0.009 ppm respectively (Tables 1 and 2). As observed in our study as the number of space maintainers increased the release of nickel also increased. Similar, results were seen in a study done by Bhaskar V and Subba Reddy $(2010)^{10}$ which also showed the increase proportionality of number of space maintainers with nickel release.

Total release of chromium in subgroups 1 and 2 was nil for Dantauram, Dtech and Rocky Mountain except for the 1st day in Rocky mountain group release on day 1 was 0.008 ppm. In subgroup 3, the total release of chromium from 1 to 28 days for Dantauram, Rocky mountain and Dtech was 0.002,0.684 and 0.012 ppm respectively, and in subgroup 4, it was $0.018,0.068$ and 0.009 ppm for the three groups repectively (Tables 3 and 4). It was observed that with an increasing time frame the release of chromium decreased and similar results were seen in a study done by Bhaskar V and Subba Reddy (2010). ${ }^{10}$

In the present study, it was observed that, as the immersion time increased in all subgroups, there was a decrease in nickel and chromium release from all space maintainers. Nickel and chromium release was nil in all subgroups on 28 th day. Similarly in a study done by Subba 
Table 3: Release of chromium ions in subgroups 1 and 2 in ppm

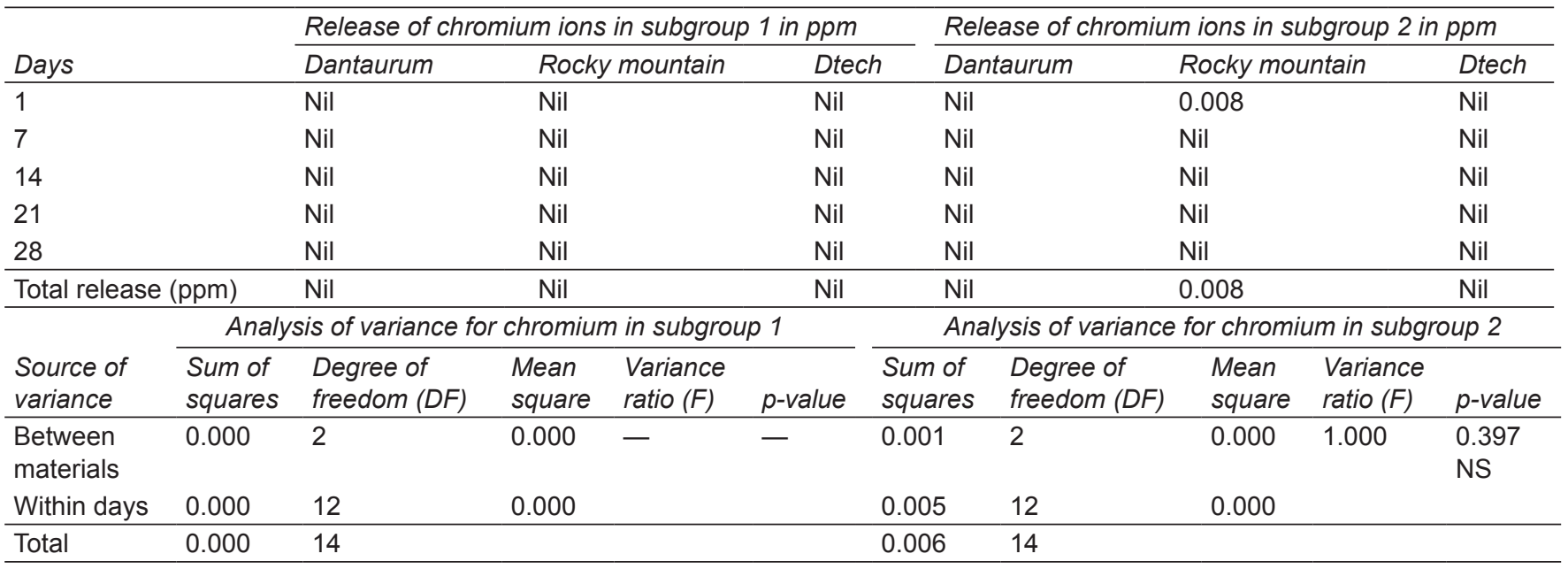

NS: Nonsignificant

Table 4: Release of chromium ions in subgroups 3 and 4 in ppm

\begin{tabular}{|c|c|c|c|c|c|c|c|c|c|}
\hline \multirow{2}{*}{\multicolumn{2}{|c|}{ Days }} & \multicolumn{4}{|c|}{ Release of chromium ions in subgroup 3 in ppm } & \multicolumn{4}{|c|}{ Release of chromium ions in subgroup 4 in ppm } \\
\hline & & \multirow{2}{*}{$\begin{array}{l}\text { Dantaurum } \\
\mathrm{Nil}\end{array}$} & \multicolumn{2}{|c|}{ Rocky mountain } & Dtech & \multicolumn{2}{|c|}{ Dantaurum } & Rocky mountain & Dtech \\
\hline \multicolumn{2}{|l|}{1} & & 0.142 & & 0.012 & Nil & & 0.037 & Nil \\
\hline \multicolumn{2}{|l|}{7} & 0.002 & 0.253 & & Nil & 0.0 & & 0.031 & Nil \\
\hline \multicolumn{2}{|l|}{14} & Nil & 0.289 & & Nil & 0.0 & & Nil & 0.009 \\
\hline \multicolumn{2}{|l|}{21} & Nil & Nil & & Nil & Nil & & Nil & Nil \\
\hline \multicolumn{2}{|l|}{28} & Nil & Nil & & Nil & Nil & & Nil & Nil \\
\hline \multicolumn{2}{|c|}{ Total release $(\mathrm{ppm})$} & 0.002 & 0.684 & & 0.012 & 0.0 & & 0.068 & 0.009 \\
\hline \multirow[b]{2}{*}{$\begin{array}{l}\text { Source of } \\
\text { variance }\end{array}$} & \multicolumn{5}{|c|}{ Analysis of variance for chromium in subgroup 3} & \multicolumn{4}{|c|}{ Analysis of variance for chromium in subgroup 4} \\
\hline & $\begin{array}{l}\text { Sum of } \\
\text { squares }\end{array}$ & $\begin{array}{l}\text { Degree of } \\
\text { freedom (DF) }\end{array}$ & $\begin{array}{l}\text { Mean } \\
\text { square }\end{array}$ & $\begin{array}{l}\text { Variance } \\
\text { ratio }(F)\end{array}$ & $p$-value & $\begin{array}{l}\text { Sum of } \\
\text { squares }\end{array}$ & $\begin{array}{l}\text { Degree of } \\
\text { freedom (DF) }\end{array}$ & $\begin{array}{l}\text { Variance } \\
\text { ratio }(F)\end{array}$ & p-value \\
\hline $\begin{array}{l}\text { Between } \\
\text { materials }\end{array}$ & 0.061 & 2 & 0.031 & 4.940 & 0.027 & 0.000 & 2 & 1.479 & $0.267 \mathrm{NS}$ \\
\hline Within days & 0.074 & 12 & 0.006 & & & 0.002 & 12 & 0.000 & \\
\hline Total & 0.135 & 14 & & & & 0.002 & 14 & & \\
\hline
\end{tabular}

NS: Nonsignificant

Reddy (2010), ${ }^{10}$ they also observed that release of nickel and chromium was minimum on 28th day of immersion.

In present study, the total release of nickel in artificial saliva ranged between 0.020 and $1.524 \mathrm{ppm}$ (Tables 1 and 2) and the total release of chromium in artificial saliva ranged between 0.020 and 0.289 ppm (Tables 3 and 4). These values obtained in the present study were below the average daily dietary intake of these two metals. The dietary intake of nickel ranges from 300 to $500 \mathrm{ppm}$ per day while chromium intake varies from 50 to $200 \mathrm{ppm}$ per day. ${ }^{6}$

Although in present study, artificial saliva was used as an immersion/solution media to produce a realistic picture of human saliva to determine the release of nickel and chromium from different space maintainers, however, it would not produce natural oral environment for degradation of space maintainers for nickel and chromium.

A direct comparison between the values obtained in the present in vitro study cannot be compared with in vivo studies because of variation in methodology. In the oral cavity various factors, such as temperature, quantity and quality of saliva, plaque, physical and chemical properties of food and liquids and oral health conditions may also influence the results. In addition, composition of saliva may be affected by many physiological variables, such as time of the day, health conditions, diet and salivary flow rate may also affect the outcome.

The results of the present study suggests that there was no substantial release of nickel and chromium from space maintainers made of Dantaurum, Rocky mountain and Dtech which could cause any toxicity.

Further, studies are needed to determine the amount of metal ions released from space maintainers and orthodontic stainless steel appliances.

\section{CONCLUSION}

Total release of nickel and chromium from all band and loop space maintainers ranged from 0.020 to $1.524 \mathrm{ppm}$ and $0.002 \mathrm{ppm}$ to $0.289 \mathrm{ppm}$ respectively. The release 
of nickel and chromium was very much below when compared with the average dietary intake of nickel (300$500 \mathrm{ppm} /$ day) and for chromium which ranges from (50-200 ppm/day) which were not capable of causing any toxic effects. There was no significant difference of release between the space maintainers made with different band materials.

\section{REFERENCES}

1. Bhaskar V, Subba Reddy VV. Biodegradation of nickel and chromium from stainless steel crowns and space maintainers - an in vitro study. J Ind Soc Pedod Prev Dent 2010 Jan-Mar;28(1):6-12.

2. Singh D, Sehgal V, Pradhan K, Chandana A, Gupta R. Estimation of nickel and chromium in saliva of patients with fixed orthodontic appliances. World J Orthod 2008;9(3):196-202.

3. Petomenou E, Arndt M, Keilig L, Reimann S, Hoederath H, Eliades T, Jager A, Bourauel C. Nickel concentration in the saliva of patients with nickel-titanium orthodontic appliances. Am J Ortho Dentofac Orthop 2009;135(1):59-65.
4. Fors R, Persson M. Nickel in dental plaque and saliva in patients with and without orthodontic appliances. Eur J Orthod 2006;28(3):292-297.

5. Petomenou E, Arndt M, Keilig L, Reimann S, Hoederath H, Eliades T, Jager A, Bourauel C. Nickel concentration in the saliva of patients with nickel-titanium orthodontic appliances. Am J Ortho Dentofac Orthop 2009;135(1):59-65.

6. Agaoglu G, Arun T, Izgu B, Yarat A. Nickel and chromium levels in the saliva and serum of patients with fixed orthodontic appliances. Angle Orthod 2001;71(5):375-379.

7. Grimsdottir M, Odont C, Gjerdt N, Pettersen A. Composition and in vitro corrosion of orthodontic appliances. Am J Orthod Dentofac Orthop 1992;101(6):525-532.

8. Barrett R, Bishara S, Quinn J. Biodegradation of orthodontic appliances. Part I. Biodegradation of nickel and chromium in vitro. Am J Orthod Dentofac Orthop 1993;103(1):8-14.

9. Fors R, Persson M. Nickel in dental plaque and saliva in patients with and without orthodontic appliances. Eur J Orthod 2006;28(3):292-297.

10. Bhaskar V, Reddy VV. Biodegradation of nickel and chromium from space maintainers - an in vitro study. J Ind Soc Pedod Prevent Dent 2010;28(1):6-12. 